\title{
An Interesting Case of Acute Myeloid Leukaemia Presented with Cerebrovascular Embolism and Native Aortic Valve Thrombus Developed Under NOAC Treatment for Pulmonary Embolism
}

\author{
Pulmoner Emboli için Verilen NOAK Tedavisi Altında Gelişen Doğal Aort Kapak Trombüsü ve \\ Serebrovasküler Emboli ile Başvuran Illginç Akut Miyeloid Lösemi Olgusu
}

(1) Hosameldin Salah Shabib Sayed Ahmed1, (1) Hüseyin Ede², (1) Hafiz Hamid Habib1, (1) Willington Francis², (1) Sherif Mahmoud Helmy A. Helmy1, (1) Awad A. Razaq Al-Qahtani1, (1) Nidal Ahmad Asaad1

${ }_{1}^{1}$ Heart Hospital, Hamad Medical Corporation, Department of Cardiology, Doha, Qatar

2 Heart Hospital, Hamad Medical Corporation, Department of Radiology, Doha, Qatar

\section{Abstract}

Acute myeloid leukemia (AML) can manifest with different signs and symptoms. Acute pulmonary embolism and cranial vascular events are some of these manifestations. However, development of valvular thrombus in the patients without inheritable thrombophilia is extremely rare. Here, we presented a very rare case of AML manifested with multiple cerebrovascular embolisms and a large, mobile native aortic valve thrombus developed under apixaban treatment for unprovoked pulmonary embolism.

Key Words: Echocardiography, Leukemia, Pulmonary Embolism, Aortic Valve Thrombus

\section{Öz}

Akut miyeloid lösemi (AML) değişik bulgu ve belirtiler ile başvurabilir. Akut pulmoner emboli ve kraniyal vasküler olaylar bu başvuru şekillerinden bazılarıdır. Ancak, kalıtsal trombofili olmaksızın hastalarda kapak trombüsü gelişmesi nadirdir. Burada, nedensiz pulmoner emboli için apiksaban tedavisi altındayken çoklu serebrovasküler emboli ve büyük, hareketli aortik kapak trombüsü ile belirti veren çok nadir bir AML olgusu sunduk.

Anahtar Kelimeler: Ekokardiyografi, Lösemi, Pulmoner Emboli, Aort Kapak Trombüsü

\section{Introduction}

Acute myeloid leukaemia (AML) is one of mostly seen hematologic malignancy and acute promyelocytic leukemia (APL) is subtype of AML and usually reveals with commonly found symptoms like fever, extreme fatigue, bleeding, shortness of breathing, hepatosplenomegaly, or lymphadenopathy (1). APL is commonly known for its coagulopathy-related complications such as bleeding and thrombotic complications such as deep vein thrombosis (DVT), pulmonary embolism, cerebral vein, and central catheter thrombosis $(2,3)$. Chemotherapy used for APL is also partially responsible for these complications (3). Percutaneous interventions and anti-coagulation are commonly used strategies used to treat these complications (1). However, efficiency of non-vitamin $\mathrm{K}$ antagonist oral anticoagulants (NOAC) such as rivaroxaban, apixaban and dabigatran in the setting of leukemia with thrombotic complications is not known clearly. Here, we presented a case of newly diagnosed APL manifested with cerebral infarcts and native aortic valve thrombus that developed while the patient was under NOAC for acute pulmonary embolism.

Address for Correspondence/Yazışma Adresi: Hüseyin Ede

Heart Hospital, Hamad Medical Corporation, Department of Radiology, Doha, Qatar

Phone: +0097450630593 E-mail: huseyinede@gmail.com ORCID ID: orcid.org/0000-0003-1218-257X

Received/Geliş Tarihi: 04.03.2021 Accepted/Kabul Tarihi: 26.07.2021

๑Telif Hakkı 2021 Ankara Üniversitesi Tıp Fakültesi

Ankara Üniversitesi Tıp Fakültesi Mecmuası, Galenos Yayınevi tarafından yayınlanmıştır.

Yayınlanan tüm içerik CC BY-NC-ND lisansı altındadır. 


\section{Case Report}

41-year-old male patient without past medical history applied to emergency department due to recurrent, atypical, more than 6-hour duration, left-sided chest pain and two-day haemoptysis with blood pressure of $118 / 75 \mathrm{mmHg}$ and oxygen saturation of $99 \%$ at room air. The patient was under 3-day amoxicillin/clavulanate tablet $1000 \mathrm{mg}$ BID given for upper respiratory tract infection before the admission to emergency department. High-sensitive troponin T-values of the patient were unremarkable $(6.4,6.1$ and $5.2 \mathrm{ng} / \mathrm{L}$ respectively). C-reactive protein was high ( $94 \mathrm{mg} / \mathrm{L})$. At admission, he had white blood cell count of $4.5 \times 10^{3} / \mathrm{uL}$, haemoglobin level of $14.0 \mathrm{gm} / \mathrm{dL}$ and platelet count of $322 \times 10^{3} / \mathrm{uL}$. The patient was tested negative for repeated Coronavirus disease-2019 polymerase chain reaction examinations. Electrocardiography showed sinus rhythm at the rate of 91 bpm without significant ST-T wave changes. Urgent computed tomographic pulmonary angiogram revealed filling defect in the pulmonary arterial tree at medial subsegmental branch of right middle lobe, subsegmental branches of the right lower lobe; subsegmental branches of left upper lobe and left lower lobes. Initial transthoracic echocardiographic examination (TTE) showed normal left ventricular ejection $(68 \%)$ with normal cardiac chamber dimensions and without any mass. Doppler examination of right lower limb showed absence of evidence of DVT but superficial vein thrombosis of great saphenous vein at its mid and distal part of thigh region. Antithrombin activity, protein $\mathrm{C}$ activity and protein $\mathrm{S}$ results were unremarkable (100.4\%, 129.4\% and 138.6\% respectively). Serum antinuclear antibody was negative. The patient was diagnosed with unprovoked pulmonary embolism and discharged with rivaroxaban $15 \mathrm{mg}$ BID. The patient developed itching-like allergic reaction to rivaroxaban at $4^{\text {th }}$ day of the treatment, thus it was changed to apixaban $5 \mathrm{mg}$ BID following 14-day treatment of enoxaparin $90 \mathrm{mg}$ subcutaneous BID.

At the $40^{\text {th }}$ day of apixaban treatment, the patient was readmitted to emergency department due to new-onset vision
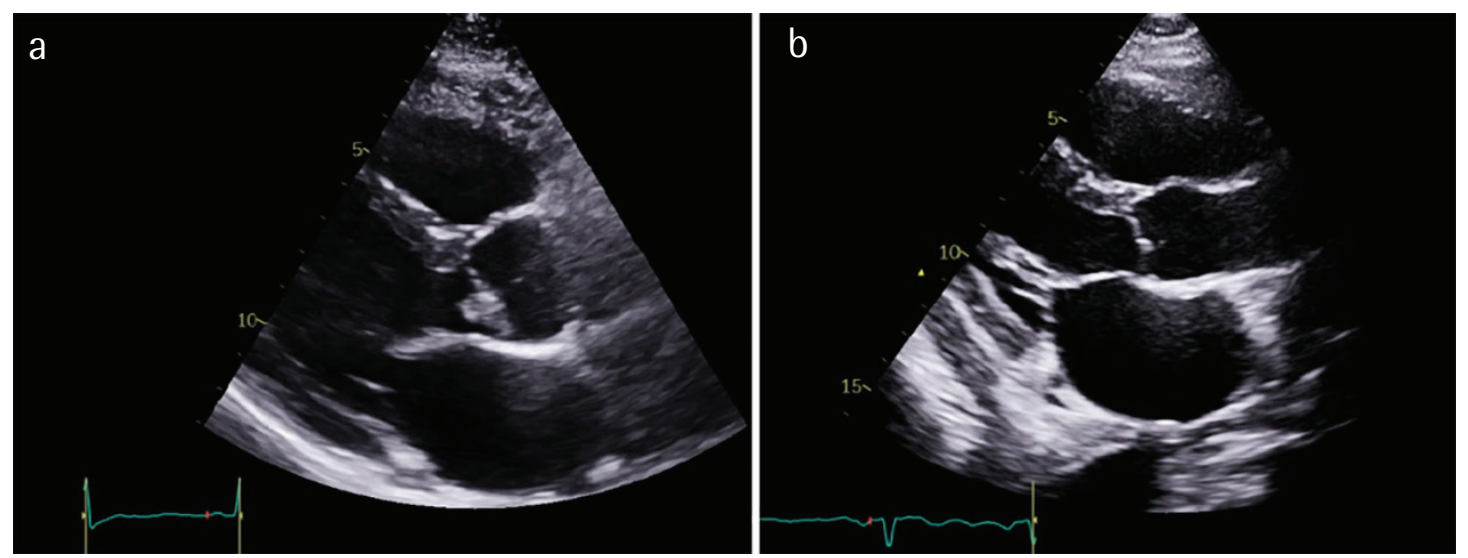

Figure 1: Transthoracic echocardiographic images. a) At the time of diagnosis, parasternal long axis image of the patient shows native aortic valve thrombus, b) after treatment with anti-coagulants and chemotherapy, parasternal long axis image of the patient shows absence of aortic valve thrombus 
of subcutaneous enoxaparin $90 \mathrm{mg}$ BID and oral aspirin $100 \mathrm{mg}$ daily treatment.

\section{Discussion}

Arterial and venous thrombotic embolisms can be seen at initial stage of AML and after chemotherapy. Here, we presented a very rare case of unprovoked pulmonary embolism diagnosed with AML who manifested with multiple cranial arterial embolisms and a large, mobile native aortic valve thrombus developed under apixaban treatment.

Thrombotic embolisms develop more commonly in APL compared to the other acute leukemias with incidence ranging from 2 to 15\% (4). However, most of the events develop after starting chemotherapy. DVT can co-exist in $70 \%$ of patients with proven pulmonary embolism (5). In our case, pulmonary embolism (PE) developed before the chemotherapy in absence of DVT. The treatment of acute PE at acute phase does not differ according to the etiology. Use of NOAC is usual practice after

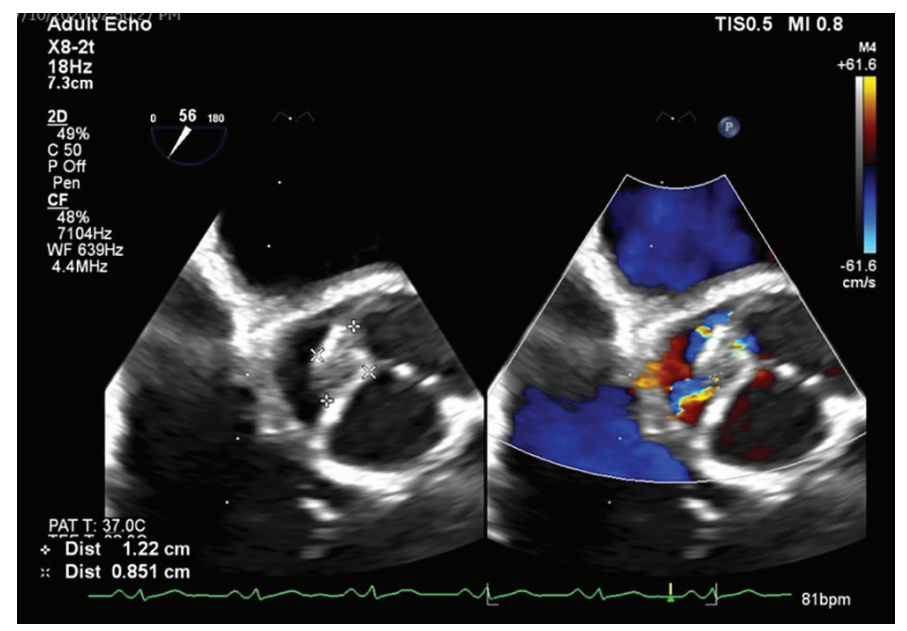

Figure 2: Transoesophageal images of the patient at mid-oesophageal level reveal thrombus attached to native aortic valve with mild eccentric insufficiency the patient with intermediate- or low-risk pulmonary embolism at outpatient setting (6). In our case, we started rivaroxaban initially, however he developed allergic reaction and it was changed to apixaban following 14-day enoxaparin treatment in between. In other words, the patient received enough anticoagulation as per the current guideline (6).

Another unique aspect of the patient was development of multiple cerebrovascular acute/subacute embolism although he was under efficient anticoagulation with apixaban for the last 40 days. In the study by Chang et al. (7), cerebral infarct was reported to be existed in 5 cases out of 127 patients with APL. But all cases with cerebral infarct developed the index event while they were under chemotherapy. In our case, all obvious and silent cerebral events developed before the chemotherapy. In the literature, there are case reports related to leukemic cell embolism (8), but it had low likelihood in our case since the peripheral smear showed leukopenia with few circulating blasts (approximately 2\%). This finding may indicate leukemia-specific coagulopathy since the patients was free of hematologic coagulopathies.

Thrombus typically develops in the cardiac structures that have low flow, resulting in blood stasis, or in patients with a mechanical prosthetic heart valve and insufficient anticoagulation. Thus, a thrombus may develop in the left ventricle, left atrium, or on a prosthetic valve $(9,10)$. Development of a thrombus over a naive, tricuspid aortic valve is extremely rare in a patient without inheritable thrombophilia $(11,12)$. In our case, there was a large, mobile thrombus attached the aortic valve without creating significant regurgitation or flow gradient. Interestingly, it developed while the patient under NOAC treatment with apixaban. Although there is no specific guideline-based treatment strategy for native valve thrombosis (10), we followed medical treatment strategy with enoxaparin while considering the underlying leukemia and NOAC failure to prevent the formation of valvular thrombosis.

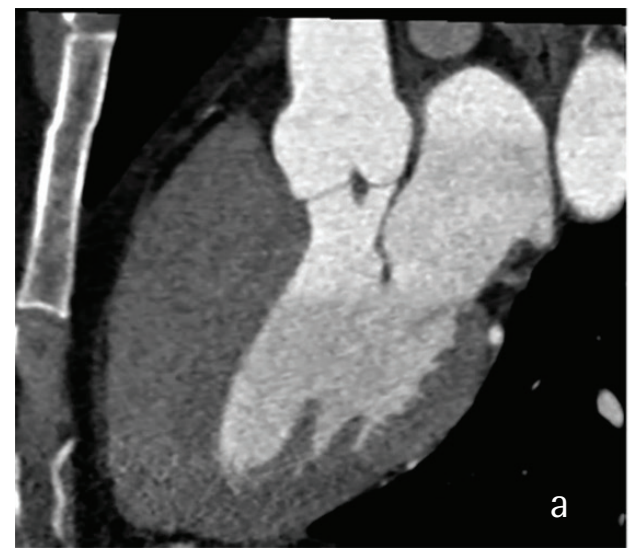

Figure 3: At the left ventricular outflow tract (a) and aortic root (b) images, cardiac computed tomography shows presence of the thrombus 


\section{Conclusion}

Development of naive aortic valve thrombus in a patient without inheritable thrombophilia as an initial manifestation of AML/APL along with preceding acute pulmonary embolism and multiple cerebral infarcts is extremely rare. Use of NOAC in a setting of acute pulmonary embolism/DVT is well established but their efficiency may not be enough to treat or prevent the development of valvular thrombus and its related embolic complications in patient with AML/APL.

\section{Ethics}

Informed Consent: Informed consent was obtained from the patient.

Peer-reviewed: Externally peer-reviewed.

\section{Authorship Contributions}

Surgical and Medical Practices: H.S.S.S.A., H.E., H.H.H., W.F., S.M.H.A.H., A.R.A.Q., N.A.A., Concept: H.S.S.S.A., H.E., Design: H.S.S.S.A., H.E., Data Collection or Processing: H.S.S.S.A., H.E., H.H.H., W.F., S.M.H.A.H., A.R.A.Q., N.A.A., Analysis or Interpretation: H.S.S.S.A., H.E., H.H.H., W.F., S.M.H.A.H., A.R.A.Q., N.A.A., Literature Search: H.S.S.S.A., H.E., H.H.H., W.F., S.M.H.A.H., A.R.A.Q., N.A.A., Writing: H.S.S.S.A., H.E.

Conflict of Interest: No conflict of interest was declared by the authors.

Financial Disclosure: The authors declared that this study received no financial support.

\section{References}

1. Chavez MA, Heidari B, Thacker S, et al. Acute Promyelocytic Leukemia Presenting as Bilateral Acute Limb Ischemia and ST Elevation Myocardial Infarction: A Case Report. Cureus. 2020;12:e8495.

2. Haider AS, Sumdani $H$, McCaslin J, et al. Aggressive Endovascular Management of Massive Dural Venous Sinus Thrombosis in the Setting of Acute Myeloid Leukemia. Cureus. 2019;11:e3891.

3. Rashidi A, Silverberg ML, Conkling PR, et al. Thrombosis in acute promyelocytic leukemia. Thromb Res. 2013;131:281-289.

4. Sorà $F$, Chiusolo $P$, Laurenti $L$, et al. Massive Pulmonary Embolism at the Onset of Acute Promyelocytic Leukemia. Mediterr J Hematol Infect Dis. 2016;8:e2016027.

5. Hull RD, Hirsh J, Carter CJ, et al. Pulmonary angiography, ventilation lung scanning, and venography for clinically suspected pulmonary embolism with abnormal perfusion lung scan. Ann Intern Med. 1983;98:891-899.

6. Konstantinides SV, Meyer G, Becattini C, et al. 2019 ESC Guidelines for the diagnosis and management of acute pulmonary embolism developed in collaboration with the European Respiratory Society (ERS). Eur Heart J. 2020;41:543-603.

7. Chang $\mathrm{H}$, Kuo MC, Shih LY, et al. Acute promyelocytic leukemia-associated thrombosis. Acta Haematol. 2013;130:1-6.

8. Mangal AK. Cerebrovascular accident due to embolism of a leukemic thrombus. Can Med Assoc J. 1984;131:428.

9. De Martino A, Falcetta G, Colli A. Early Valve Thrombosis in Surgical Aortic Bioprosthesis: Rare or Underestimated Event? J Am Coll Cardiol. 2020;76:1812.

10. Baumgartner H, Falk V, Bax JJ, et al. 2017 ESC/EACTS Guidelines for the management of valvular heart disease. Eur Heart J. 2017;38:2739-2791.

11. Jones $\mathrm{CB}$, Draughn T, Nomeir AM. Aortic valve thrombus presenting as a nonST elevation myocardial infarction. J Am Soc Echocardiogr. 2008;21:876.e1-

12. Vermeersch G, Prihadi E, De Keulenaer G, et al. Giant native aortic valve thrombus under non-vitamin $\mathrm{K}$ antagonist oral anticoagulant: first manifestation of antiphospholipid syndrome. Eur Heart J. 2021;42:1927. 